\title{
Effects of hydrophobic $\mathrm{CaO}$ and $\mathrm{SiO}_{2}$ nanoparticles on Asphaltene Precipitation Envelope (APE): an experimental and modeling approach
}

\author{
Yaser Ahmadi ${ }^{1}$, and Babak Aminshahidy, ${ }^{1, *}$ \\ ${ }^{1}$ Department of Petroleum Engineering, Amirkabir University of Technology (Polytechnic), Hafez Avenue, 15875-4413 Tehran, Iran
}

Received: 29 April 2018 / Accepted: 10 August 2018

\begin{abstract}
An experimental and modeling approach was developed in this research to investigate the effects of $\mathrm{CO}_{2}$, new synthesized $\mathrm{CaO}$ and commercial $\mathrm{SiO}_{2}$ nanoparticle concentrations on the Asphaltene Precipitation Envelope (APE). First, the effects of different temperatures and $\mathrm{CO}_{2}$ concentrations on asphaltene precipitation trends were observed. Second, the impact of $\mathrm{CaO}$ and $\mathrm{SiO}_{2}$ nanoparticle concentrations on asphaltene precipitation were observed in the presence of $\mathrm{CO}_{2}$ at different temperatures. Third, Advanced RedlichKwong-Soave (RKSA) equation of state (EOS) was considered to modify Multiflash (Infochem Co.) software from the aspect of entering physical characteristics of $\mathrm{CaO}$ and $\mathrm{SiO}_{2}$ nanoparticles as pseudo components. Fourth, the developed model was used for predicting the effects of $\mathrm{CO}_{2}, \mathrm{CaO}$ and $\mathrm{SiO}_{2}$ concentrations on APE in ranges that no experimental data existed. At constant $\mathrm{CO}_{2}$ concentration and temperature during natural depletion, asphaltene precipitation increased above saturation pressure, while below saturation pressure, asphaltene precipitation decreased (solution gas evolved from crude oil and made it richer). As temperature increased at constant $\mathrm{CO}_{2}$ concentration, asphaltene precipitation decreased, while it was observed that the saturation pressures increased. Although two different trends were observed in upper asphaltene onsets at different temperatures and $\mathrm{CO}_{2}$ concentrations, in wide ranges of data, as temperature increased, asphaltene upper onset pressure increased. $\mathrm{CaO}$ and $\mathrm{SiO}_{2}$ nanoparticles decreased asphaltene precipitations in the presence of $\mathrm{CO}_{2}$, but $\mathrm{CaO}$ had better applications for reducing asphaltene precipitation. The proposed Software/RKSA EOS model was in good agreement with the obtained experimental data, and it was applicable for predicting the effects of $\mathrm{CO}_{2}, \mathrm{CaO}$ and $\mathrm{SiO}_{2}$ nanoparticles concentration on APE.
\end{abstract}

\section{Nomenclature}

AOP Asphaltene Onset Pressure

APE Asphaltene Precipitation Envelope

$\mathrm{CaO}$ Calcium oxide

CII Colloidal Instability Index

$\mathrm{CO}_{2} \quad$ Carbon dioxide

HP-HT High Pressure-High Temperature

$K_{i j} \quad$ Binary interaction between components i and $j$

$n_{i, j} \quad$ Molar fractions of components

$P_{\text {ci }} \quad$ Critical pressure (Psi)

ppm Parts per million

$R \quad$ Gas constant

SEM Scanning Electron Microscope

$\mathrm{SiO}_{2} \quad$ Silicon dioxide

SARA Saturate-Aromatic-Resin-Asphaltene

$T_{\mathrm{b}} \quad$ Boiling temperature $\left({ }^{\circ} \mathrm{F}\right)$

* Corresponding author: aminshahidy@aut.ac.ir
$T_{\text {ci }} \quad$ Critical temperature $\left({ }^{\circ} \mathrm{C}\right)$

W Acentric factor

\section{Introduction}

Crude oil has main fractions including Saturates, Aromatics, Resins and Asphaltenes. Asphaltenes contain carbon, hydrogen and heteroelements including oxygen, sulfur and nitrogen [1]. Asphaltenes stability depends on asphaltene characteristics and crude oil's properties, and disturbed asphaltenes stability causes asphaltene precipitation [2, 3]. Asphaltene precipitation occurred due to changes in pressures, temperatures and compositions, which created a serious problem in the production of reservoir oil [4-16]. Precipitated asphaltene caused many problems in wellbore tubing and equipment [14]. 
Bouts et al. [17] investigated the interactions between crude oil's fractions and asphaltenes. It was observed that the asphaltene precipitation decreased at a high ratio of resin to asphaltene, and the resin polar head coated asphaltene molecules and the nonpolar parts interacted directly with oil [17]. Asphaltenes stability was analyzed by many methods including: the Colloidal Instability Index (CII) [18, 19], De Boer's diagram [20], Refractive index [3] and hydrogen to carbon ratio [21]. Asphaltenes Precipitation Envelopes (APE), gravimetric, acoustic resonance, nearinfrared light scattering and filtration were the most common methods for detecting the severity of asphaltenes [20]. Akbarzadeh et al. [22] performed a study on the flow assurance problem due to asphaltene precipitation. They found out that due to changes in equilibrium conditions and resin in crude oil, asphaltenes stuck together and these particles came to the surface.

Many asphaltene precipitation treatments were used for solving precipitation problems such as chemical solvent treatment [23], thermal treatments and laser technology [2] and inhibitors such as alkyl phenol, ethoxylated alcohols, phenols, natural resin, and vegetable oil [3]. Since these methods were expensive and nanoparticles had special characteristics including high ability to adsorb asphaltene on its surface and high specific surface volume, researchers used the adsorption of asphaltene on the nanoparticles surface for asphaltene precipitation inhibition [24-29].

Asphaltene characteristics [30], amount of resins [31, 32], solvent polarity [33, 34], particle surface chemistry [35], and temperature and contact time [36-38] were the main parameters that affected the adsorption process. Nassar et al. [24-29] have published several reports on the adsorption of asphaltene on the nanoparticles surface. Based on their results, $\mathrm{CaO}$ nanoparticle had the highest adsorption capacity as compared with nanoparticles such as Nicole oxide and Titanium dioxide. $\mathrm{CaO}$ had many applications such as biomedical, water purification, adsorption and antibacterial agents [39-41]. Although asphaltene adsorption on $\mathrm{CaO}$ nanoparticle was surveyed, almost no work addressed the effects of $\mathrm{CaO}$ nanoparticle on asphaltene precipitation reduction, Asphaltene Onset Pressure (AOP) and APE envelope. As the deposition of asphaltenes in the porous media was known as one of the most difficult problems during $\mathrm{CO}_{2}$ flooding [42-46], $\mathrm{CO}_{2}$ and natural depletion tests were used as sources of making asphaltene precipitation in this paper. In the first phases of this paper, the effects of different temperatures and $\mathrm{CO}_{2}$ concentrations on asphaltene precipitation trends were observed. Then, the impacts of $\mathrm{CaO}$ nanoparticle concentrations on the asphaltene precipitation were observed in the presence of $\mathrm{CO}_{2}$ at different temperatures. $\mathrm{SiO}_{2}$ nanoparticles have been addressed in many studies for asphaltene inhibition [47-49], so the results of the new synthesized $\mathrm{CaO}$ nanoparticles are compared with commercial $\mathrm{SiO}_{2}$ nanoparticles as the next step in this research.

Leontaritis and Mansoori [50] proposed a model for prediction of asphaltene flocculation based on thermodynamics, and asphaltene was considered as a solid particle that was stabilized with resin. Moreover, some models such as those by $\mathrm{Wu}$ et al. [51] considered asphaltene as
Table 1. Properties of crude oil used in PVT modeling.

\begin{tabular}{|c|c|c|c|}
\hline Component & $\begin{array}{c}\text { Separated } \\
\text { oil (mole. } \\
\%)\end{array}$ & $\begin{array}{c}\text { Separated } \\
\text { gas (mole. } \\
\% \text { ) }\end{array}$ & $\begin{array}{c}\text { Reservoir oil (mole. } \\
\% \text { ) }\end{array}$ \\
\hline $\mathrm{H}_{2} \mathrm{~S}$ & 0.00 & 0.13 & 0.01 \\
\hline $\mathrm{N}_{2}$ & 0.00 & 0.91 & 0.08 \\
\hline $\mathrm{CO}_{2}$ & 0.00 & 6.71 & 0.56 \\
\hline $\mathrm{C}_{1}$ & 0.00 & 41.38 & 3.44 \\
\hline $\mathrm{C}_{2}$ & 0.27 & 19.52 & 1.88 \\
\hline $\mathrm{C}_{3}$ & 2.35 & 15.55 & 3.45 \\
\hline$i \mathrm{C}_{4}$ & 1.12 & 2.41 & 1.23 \\
\hline$n \mathrm{C}_{4}$ & 5.70 & 6.63 & 5.77 \\
\hline$i \mathrm{C}_{5}$ & 3.85 & 2.08 & 3.70 \\
\hline$n \mathrm{C}_{5}$ & 5.57 & 2.30 & 5.30 \\
\hline $\mathrm{C}_{6}$ & 6.30 & 1.74 & 5.92 \\
\hline $\mathrm{C}_{7}^{+}$ & 74.84 & 0.63 & 68.67 \\
\hline \multicolumn{3}{|c|}{$\mathrm{GOR}(\mathrm{SCF} / \mathrm{STB})$} & 237.0 \\
\hline \multicolumn{3}{|c|}{ Molecular weight of residual oil } & 250.0 \\
\hline \multicolumn{3}{|c|}{ Molecular weight of $\mathrm{C}_{7}^{+}$fraction } & 310.0 \\
\hline \multicolumn{3}{|c|}{ Molecular weight of Reservoir oil } & 232.0 \\
\hline \multicolumn{3}{|c|}{ Sp.Gr. of $\mathrm{C}_{7}{ }^{+}$Fraction @ 60/60 ${ }^{\circ} \mathrm{F}$} & 0.959 \\
\hline \multicolumn{3}{|c|}{ Saturate $\%$} & 56.2 \\
\hline \multicolumn{3}{|c|}{ Aromatic $\%$} & 34.1 \\
\hline \multicolumn{3}{|c|}{ Resin \% } & 7.7 \\
\hline \multicolumn{3}{|c|}{ Asphaltene $\%$} & 2.0 \\
\hline
\end{tabular}

liquid-liquid treatments with oil. Flash calculation between liquid-vapor-asphalt was used as another method for the modeling of asphaltene precipitation during gas injection and pressure depletion, which was proposed by Nghiem et al. [52]. The proposed model was not good at high concentrations of gas concentration. Victorov and Firoozabadi [53] performed experimental works based on the miscillazation model, and the proposed model was in good agreement with many experimental works. However, it was not good for the prediction of asphaltene during gas flooding. Although multiphase simulators such as Pipesim, Well Flo, Eclipse 300 and Olga are used for investigating the system that contains asphaltene under normal and abnormal conditions [54, 55], having software for modeling the inhibitor or nanoparticles as an inhibitor is completely necessary. Accordingly, in the second phases of this paper, the Advanced Redlich-Kwong-Soave (RKSA) equation of state was considered to modify Multiflash (Infochem Co.) software from the aspect of entering physical characteristics of synthesized $\mathrm{CaO}$ and commercial $\mathrm{SiO}_{2}$ nanoparticles as pseudo components. Finally, the developed model was used for predicting the effects of different parameters such as $\mathrm{CaO}$ and $\mathrm{SiO}_{2}$ nanoparticles and $\mathrm{CO}_{2}$ concentrations on $\mathrm{APE}$ in ranges that no experimental data existed. Using software is cost-effective and this study can be a source of the first preliminary attempt at modeling nanoparticles as asphaltene inhibitors. 


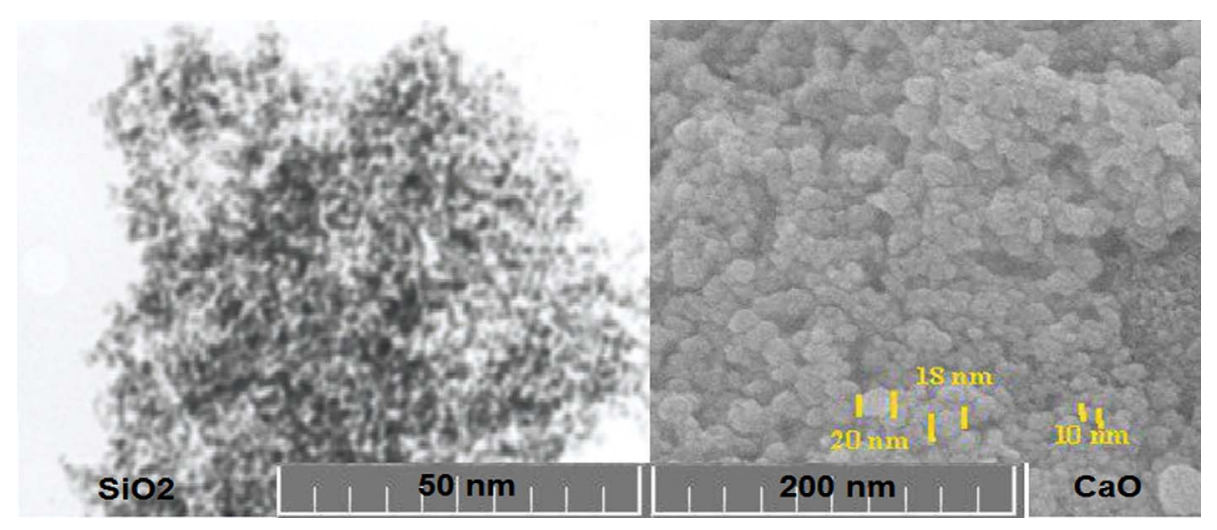

Fig. 1. Scanning Electron Microscope (SEM) for hydrophobic CaO (right) and hydrophobic $\mathrm{SiO}_{2}($ left).

\section{Experimental}

\subsection{Materials and methodology}

A crude oil was selected from an Iranian reservoir in the west of Iran. Table 1 shows properties of crude oil and Saturate-Aromatic-Resin-Asphaltene (SARA) test results, which are used in PVT modeling.

Equation (1) expressed CII, and if the CII value is more than 0.9 , it shows very unstable conditions $[56,57]$. According to the SARA results in the current study, CII is 1.392, which confirms that crude oil is located in an unstable region.

$$
\mathrm{CII}=\frac{\text { Saturates }+ \text { Asphaltenes }}{\text { Aromatics }+ \text { Resins }}
$$

Asphaltene is extracted by the IP143 method. Nassar et al. [28] carried out a study on asphaltene extraction's protocol. Briefly, asphaltene was diluted with n-heptane at a volume ratio of $40 / 1$ and mixtures remained in the dark box for $24 \mathrm{~h}$. Then Whatman paper was used for filtration of pure asphaltene. Hydrophobic commercial $\mathrm{SiO}_{2}$ and synthesized $\mathrm{CaO}$ were used as nanoparticles for precipitation tests. $\mathrm{CaO}, 20 \mathrm{~nm}$ were synthesized based on Singh and Singh's [58] work, and $\mathrm{SiO}_{2}$ was bought from Houston Brand company. The SEM of these two nanoparticles is shown in Figure 1.

$\mathrm{CaO}$ and $\mathrm{SiO}_{2}$ nanoparticles were stirred in crude oil solution for $6 \mathrm{~h}$ and sonicated for $30 \mathrm{~min}$ to stay stable in crude oil.

\subsection{Natural depletion tests in presence of different concentrations of carbon dioxide $\left(\mathrm{CO}_{2}\right)$}

Figure 2 shows the schematic of the apparatus for measuring asphaltene precipitation during $\mathrm{CO}_{2}$ and depletion tests. The set up mainly contained PVT cell, recombination sampling cells, hydraulic pumps, 0.5 micron filter, $\mathrm{CO}_{2}$ cylinder, IP143 set up and oven. Samples including: A) crude oil and separator gas; B) crude oil [containing $\mathrm{CaO}$ ] and separator gas; C) crude oil [containing $\mathrm{SiO}_{2}$ ] and separator gas were prepared, and a recombination was performed for 2 weeks at reservoir pressure and temperature. Then, the prepared samples were transferred from recombination cell ${ }^{2}$ to $\mathrm{PVT}$ cell ${ }^{3}$ and the desired concentration of $\mathrm{CO}_{2}$ was injected to the PVT cell and kept for $24 \mathrm{~h}$ at the desired pressure and temperature. Next, the sample was passed through a 0.5 micron metal filter ${ }^{4}$ and the sample was collected in a sampling cell. Asphaltenes and nanoparticles, which adsorbed asphaltene on their surface and had a size of more than 0.5 microns, could not cross the filter. Finally, the sample was obtained from the sampling cell, and asphaltene content was calculated from the IP143 method. Asphaltene precipitation was calculated from the difference between asphaltene content in the PVT cell sample and the obtained sample in the sampling cell.

\section{Results and discussion}

\subsection{Experimental}

\subsubsection{Effects of carbon dioxide $\left(\mathrm{CO}_{2}\right)$ concentrations and temperatures on asphaltene precipitation during natural depletion}

Figure 3 shows the effects of $\mathrm{CO}_{2}$ concentrations $(10 \%, 20 \%$ and $30 \%$ ) and temperatures $\left(80^{\circ} \mathrm{C}, 90^{\circ} \mathrm{C}\right.$ and $\left.100{ }^{\circ} \mathrm{C}\right)$ on asphaltene precipitation during natural pressure depletions. Two different trends were seen during natural pressure depletions. Above saturation pressure, asphaltene precipitation increased while below saturation pressure asphaltene precipitation decreased. The maximum amount of asphaltene precipitations occurred at saturation pressures. The reasons for these trends were understood by the solubility approach. Briefly, at constant temperature and during natural depletion above saturation pressure, density and fluid power decreased. However, by decreasing pressure below saturation pressure, solution gas evolved from crude oil and oil became subsequently richer [59, 60].

According to the results in Figure 3, as temperature increased from $80{ }^{\circ} \mathrm{C}$ to $100{ }^{\circ} \mathrm{C}$, asphaltene precipitation decreased while it was seen that the saturation pressures increased due to an increase of temperatures. Results were different and inconsistent with each other regarding the 


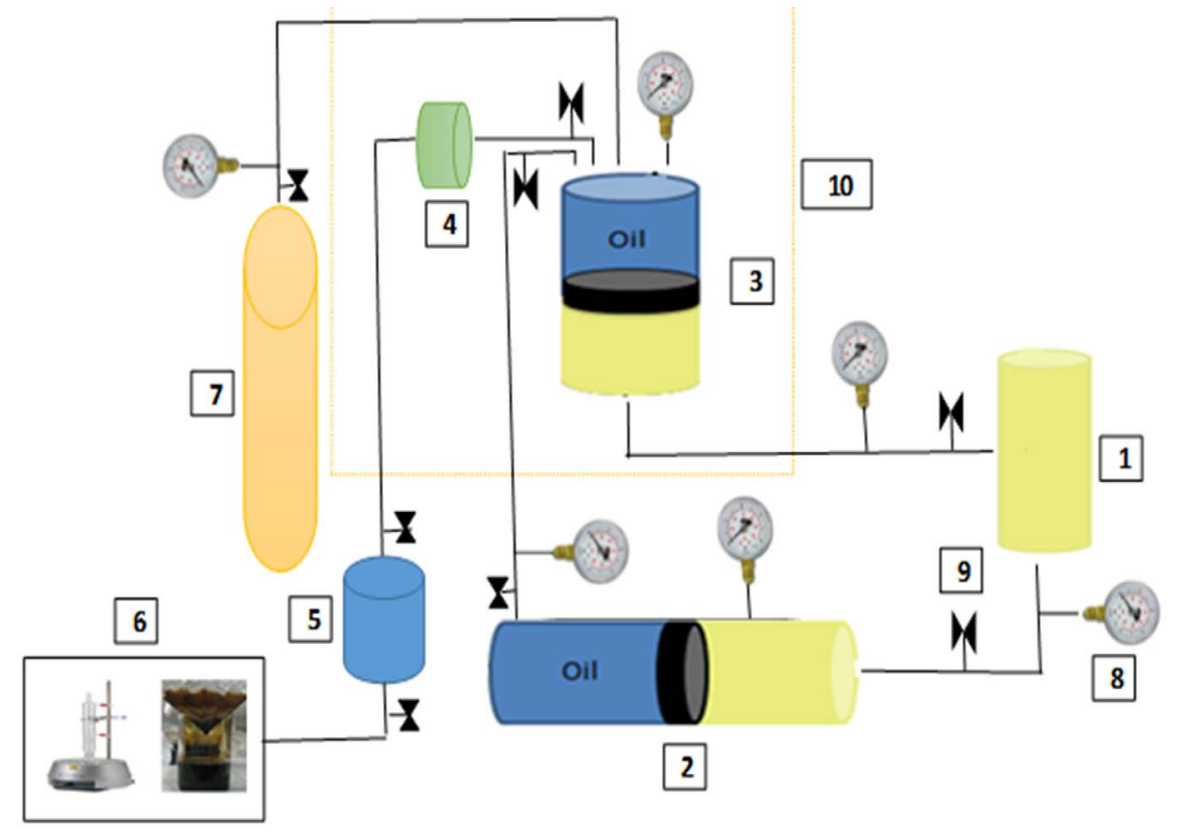

1) hydraulic pump 2) crude oil recombination cell 3) high pressure PVT cell 4) filter for asphaltene 5) sampling cell 6) IP143 set up 7) high pressure $\mathrm{CO}_{2}$ cylinder 8) pressure gauge 9) Needle valve 10) Oven for applying temperature.

Fig. 2. Schematic of apparatus for performing natural depletion tests in presence of $\mathrm{CO}_{2}$.

relation of temperature and asphaltene precipitation in the literature [61-63]. Recently, our group studied the influence of different temperature ranges on asphaltene precipitation with high pressure and high temperature experiments to survey the effects of temperature on asphaltene precipitation in heavy oil reservoirs. According to the natural depletion results, asphaltene precipitation increased from $60^{\circ} \mathrm{C}$ to $80{ }^{\circ} \mathrm{C}$ and decreased from $80{ }^{\circ} \mathrm{C}$ to $96.1{ }^{\circ} \mathrm{C}$ [63]. Thus, these results are in good agreement with the current results in this paper regarding the effects of temperature on asphaltene precipitation. Hassanvand et al. [61] and Verdier et al. [62] investigated the effects of temperature on asphaltene precipitation as well. It was shown that as temperature increased, asphaltene particles redissolved and asphaltene precipitation decreased. As it was shown in Figure 3, asphaltene precipitation increased due to the addition of $\mathrm{CO}_{2}$ concentrations. Asphaltenes are high molecular polar compounds, which are stabilized in the presence of resins. Dilution of oil with light hydrocarbons decreased the amount of resin and asphaltenes flocculated and lost their stability.

Table 2 shows experimental upper onset and saturation pressures at different temperatures $\left(80{ }^{\circ} \mathrm{C}, 90{ }^{\circ} \mathrm{C}\right.$ and $100{ }^{\circ} \mathrm{C}$ ) and $\mathrm{CO}_{2}$ concentrations (10\%, $20 \%$ and $\left.30 \%\right)$. Two different trends were observed based on experimental data including: 1) $\mathrm{CO}_{2} 10$ mole $\%$, from $90{ }^{\circ} \mathrm{C}$ to $100{ }^{\circ} \mathrm{C}$ and 2) $\mathrm{CO}_{2} 10$ mole $\%$, from $80^{\circ} \mathrm{C}$ to $90{ }^{\circ} \mathrm{C} ; \mathrm{CO}_{2} 20$ mole $\%$, from $80{ }^{\circ} \mathrm{C}$ to $100{ }^{\circ} \mathrm{C}$ and $\mathrm{CO}_{2} 30$ mole $\%$, from $80{ }^{\circ} \mathrm{C}$ to $100{ }^{\circ} \mathrm{C}$. In the first trend, as temperature increased, asphaltene upper onset pressure decreased while in the second trend, as temperature increased, asphaltene upper onset pressure increased. The second trends were observed to a greater extent in our experimental data. Negahban et al. [64] surveyed the effects of temperature on AOP of live oil. According to their results, as temperatures increased, AOP decreased [64]. This results in a good agreement with the first trend of current research, but is in contrast with the second trend. Novosad and Costain [65], Srivastava and Huang [66], Takahashi et al. [67], and Vazquez and Mansoori [68], showed that as $\mathrm{CO}_{2}$ concentration increased, AOP increased. These results are in good agreement with wide ranges of our experimental data as it was shown in Table 2.

\subsubsection{Effects of temperature and hydrophobic nanoparticles type ( $\mathrm{CaO}$ and $\left.\mathrm{SiO}_{2}\right)$ on asphaltene precipitations in the presence of $\mathrm{CO}_{2}$ during natural depletion}

Figure 4 shows the effects of temperature and nanoparticles types including $\mathrm{CaO}$ and $\mathrm{SiO}_{2}$ on asphaltene precipitations in the presence of $\mathrm{CO}_{2}$ during natural depletion. Three pressures including 2500, 2000 and 1500 Psi were used and precipitation amounts were obtained in the presence of $\mathrm{CaO}$ and $\mathrm{SiO}_{2}$ nanoparticles. According to the precipitation results, as temperature increased from $90^{\circ} \mathrm{C}$ to $100^{\circ} \mathrm{C}$ during pressure reduction from $2500 \mathrm{Psi}$ to $1500 \mathrm{Psi}, \mathrm{CaO}$ decreased asphaltene precipitation from (0.32 wt. \%, 0.62 wt. \%) to (0.096 wt. \%, 0.214 wt. \%) and $\mathrm{SiO}_{2}$ decreased asphaltene precipitation from $(0.56$ wt. $\%, 1.10$ wt. $\%)$ to $(0.27$ wt. \%, 


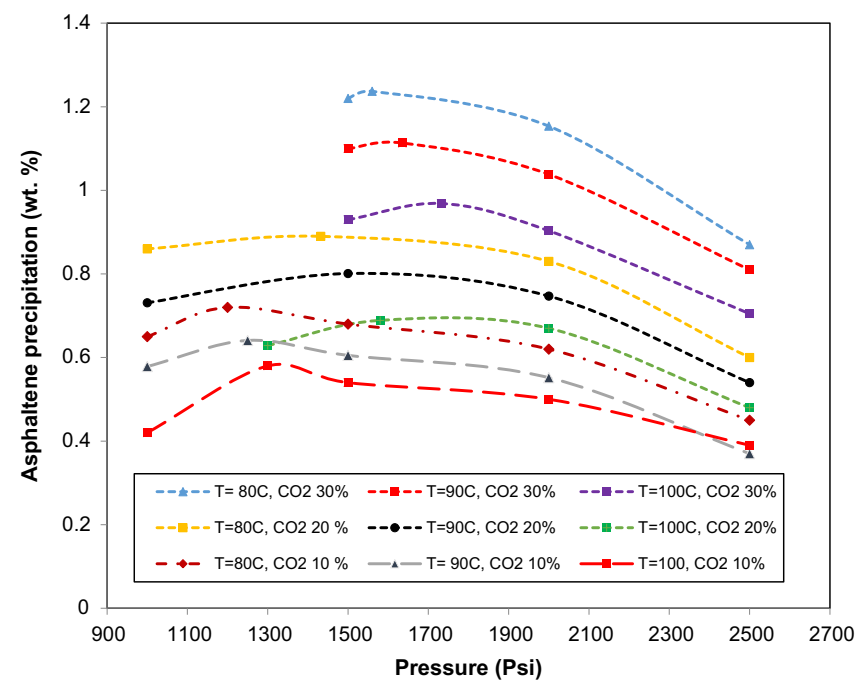

Fig. 3. Effects of $\mathrm{CO}_{2}$ concentrations and temperatures on asphaltene precipitation and saturation pressures during natural depletion.

Table 2. Experimental upper onset and saturation pressures at different temperatures and $\mathrm{CO}_{2}$ concentrations.

\begin{tabular}{cccc}
\hline $\begin{array}{c}\mathrm{CO}_{2} \\
\begin{array}{c}\text { concentration } \\
(\text { mole } \%)\end{array}\end{array}$ & $\begin{array}{c}\text { Temperature } \\
\left({ }^{\circ} \mathrm{C}\right)\end{array}$ & $\begin{array}{c}\text { Upper onset } \\
\text { pressures (Psi) }\end{array}$ & $\begin{array}{c}\text { Saturation } \\
\text { pressures } \\
(\text { Psi })\end{array}$ \\
\hline \multirow{2}{*}{10} & 80 & 3670 & 1200 \\
& 90 & 3745 & 1250 \\
20 & 100 & 3706 & 1300 \\
& 80 & 3813 & 1432 \\
& 90 & 3823 & 1500 \\
30 & 100 & 4084 & 1580 \\
& 80 & 3929 & 1560 \\
& 90 & 4258 & 1635 \\
& 100 & 4306 & 1732 \\
\hline
\end{tabular}

0.52 wt. \%), respectively. Hydrophobic $\mathrm{CaO}$ nanoparticles had better application for reducing asphaltene precipitations compared to $\mathrm{SiO}_{2}$ nanoparticles.

Two different trends were observed in upper onset pressures including $80{ }^{\circ} \mathrm{C}$ to $90{ }^{\circ} \mathrm{C}$ and $90{ }^{\circ} \mathrm{C}$ to $100{ }^{\circ} \mathrm{C}$ for both $\mathrm{CaO}$ and $\mathrm{SiO}_{2}$ nanoparticles. As the temperature increased from $80{ }^{\circ} \mathrm{C}$ to $90{ }^{\circ} \mathrm{C}$, AOP increased from 2750 Psi to 2825 Psi and 3100 Psi to 3150 Psi in the presence of $\mathrm{CaO}$ and $\mathrm{SiO}_{2}$, respectively. However, as temperature increased from $90{ }^{\circ} \mathrm{C}$ to $100{ }^{\circ} \mathrm{C}$, AOP decreased from 2825 Psi to 2790 Psi and 3150 Psi to 3130 Psi in the presence of $\mathrm{CaO}$ and $\mathrm{SiO}_{2}$, respectively. Further information is given in Table 3 .

Figure 5 compared asphaltene precipitation reductions for $\mathrm{CaO}$ and $\mathrm{SiO}_{2}$ nanoparticles at $\mathrm{CO}_{2} 30$ mole $\%$ and $80{ }^{\circ} \mathrm{C}$. As pressure decreased from $2500 \mathrm{Psi}$ to $1500 \mathrm{Psi}$, asphaltene precipitation decreased from (0.87 wt. \%, 1.22 wt. $\%)$ to $(0.32$ wt. $\%, 0.68$ wt. $\%)$ and (0.56 wt. \%,

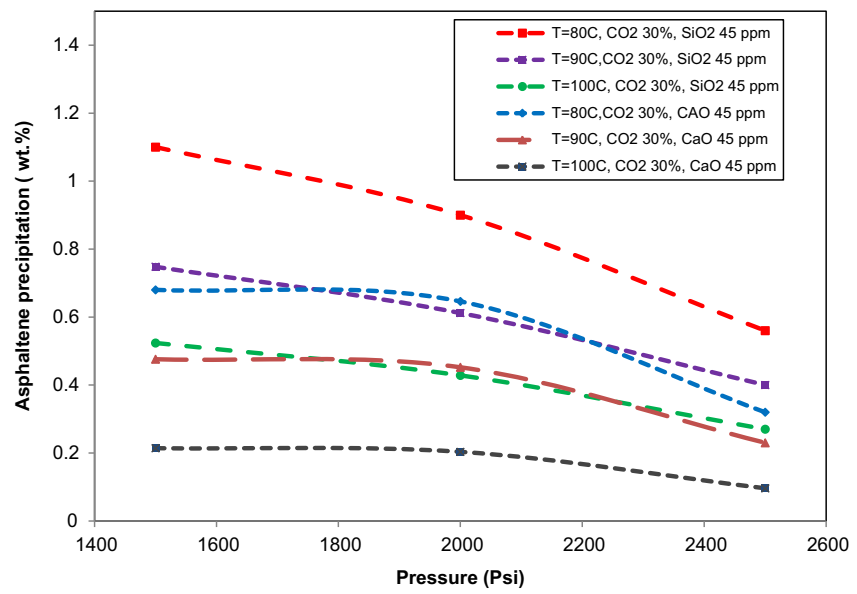

Fig. 4. Effects of temperature and nanoparticles types $(\mathrm{CaO}$ and $\mathrm{SiO}_{2}$ ) on asphaltene precipitations in the presence of $\mathrm{CO}_{2}$ during natural depletion.

Table 3. Upper onset pressures in the presence of $\mathrm{CaO}$ and $\mathrm{SiO}_{2}$ nanoparticles and $\mathrm{CO}_{2} 30$ mole. \%.

\begin{tabular}{clr}
\hline$T\left({ }^{\circ} \mathrm{C}\right)$ & \multicolumn{2}{c}{ Upper onset pressures } \\
\cline { 2 - 3 } & $\mathrm{CaO}$ & $\mathrm{SiO}_{2}$ \\
\hline 80 & 2750 & 3100 \\
90 & 2825 & 3150 \\
100 & 2790 & 3130 \\
\hline
\end{tabular}

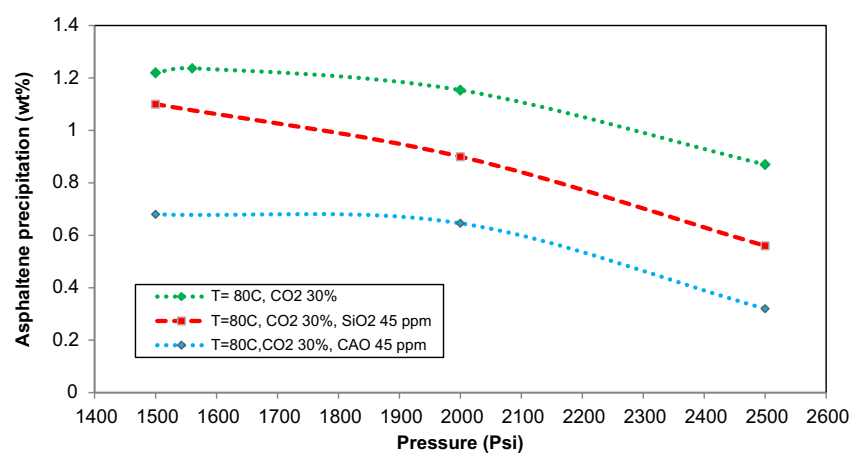

Fig. 5. Comparison of $\mathrm{CaO}$ and $\mathrm{SiO}_{2}$ nanoparticles for reducing the asphaltene precipitation at $\mathrm{CO}_{2} 30 \%$ at $80{ }^{\circ} \mathrm{C}$.

1.1 wt. \%) for $\mathrm{CaO}$ and $\mathrm{SiO}_{2}$ nanoparticles, respectively. $\mathrm{CaO}$ decreased asphaltene precipitations much better than $\mathrm{SiO}_{2}$ nanoparticles.

As discussed above, hydrophobic $\mathrm{CaO}$ had better applications for reducing asphaltene precipitations compared to $\mathrm{SiO}_{2}$. The effects of $\mathrm{SiO}_{2}$ and $\mathrm{CaO}$ nanoparticles and pressures on the interfacial tension of $\mathrm{CO}_{2}$-crude oil were obtained for a better understanding of this behavior. Table 4 shows the relation of $\mathrm{CO}_{2}$-crude oil interfacial tension equations versus pressure and different slope regions in the presence of $\mathrm{CaO}$ and $\mathrm{SiO}_{2}$ nanoparticles at a constant 
Table 4. Changes in $\mathrm{CO}_{2}$-oil IFT slope ratio due to adding $\mathrm{CaO}$ and $\mathrm{SiO}_{2}$ nanoparticles.

\begin{tabular}{ccccc}
\hline $\begin{array}{c}\text { Nanoparticles } \\
\text { type }\end{array}$ & $\begin{array}{c}\text { Nanoparticle } \\
\text { concentration } \\
(\mathrm{ppm})\end{array}$ & Region & $\begin{array}{c}\text { Equation IFT } \\
(\mathrm{mN} / \mathrm{m})\end{array}$ & $\begin{array}{c}\text { Ratio of the IFT slope } \\
\text { in 2nd to 1st region }(\%)\end{array}$ \\
\hline Base & 0 & 1st & IFT $=-0.0124 P+17.675$ & 16.9 \\
& & 2 nd & IFT $=-0.0021 P+6.137$ & 39.5 \\
$\mathrm{CaO}$ & 45 & 1st & IFT $=-0.0124 P+16.675$ & 31.0 \\
& & 2 nd & IFT $=-0.0049 P+8.407$ & \\
$\mathrm{SiO}_{2}$ & 1st & IFT $=-0.0126 P+16.909$ & IFT $=-0.0039 P+7.939$ & \\
& & 2nd & IFT &
\end{tabular}
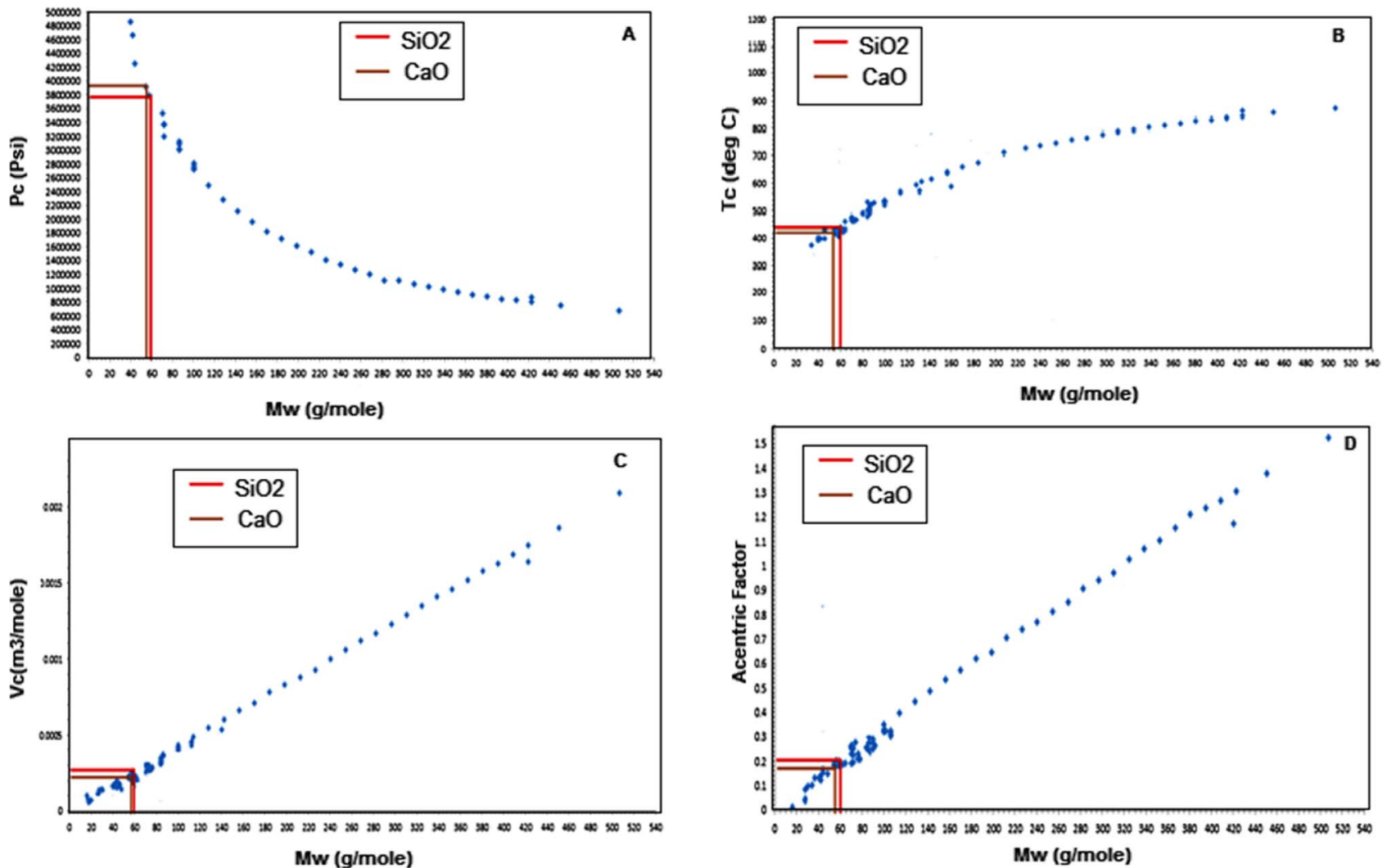

Fig. 6. Physical properties of nanoparticles $\left(\mathrm{CaO}\right.$ and $\left.\mathrm{SiO}_{2}\right)$ based on the software's information bank. A) $P_{\mathrm{c}}$ vs. Mw; B) $T_{\mathrm{c}}$ vs. $M_{\mathrm{w}}$; C) $V_{\mathrm{c}}$ vs. $\left.M_{\mathrm{w}} ; \mathrm{D}\right)$ acentric factor vs. $\mathrm{M}_{\mathrm{w}}$.

nanoparticle concentration of $45 \mathrm{ppm}$. Two different slopes were observed for all three crude oil conditions (without nanoparticles, $\mathrm{CaO} 45 \mathrm{ppm}$ and $\mathrm{SiO}_{2} 45 \mathrm{ppm}$ ). With an increase of pressure in the first region, IFT decreased due to oil swelling. In the second region, the slope became slower than the first region due to aggregation of asphaltene in the interface of the two fluids (the ratio of the 2 nd to 1st ratio was $16.9 \%$ ). After the addition of nanoparticles, although the first region slope did not change significantly, the slope in the second region increased $339.5 \%$ for $\mathrm{CaO}$ and $31.0 \%$ for $\mathrm{SiO}_{2}$ ). Interestingly, the slope increased better in the presence of $\mathrm{CaO}$ nanoparticles compared to $\mathrm{SiO}_{2}$. Accordingly, $\mathrm{CaO}$ adsorbed more asphaltene and had a better function for asphaltene inhibition in comparison to $\mathrm{SiO}_{2}$ nanoparticles. Nassar et al. [26] concluded that basic oxides such as $\mathrm{CaO}$ had higher adsorption capacity compared to other oxides, which is in good agreement with our results.

\subsection{Modeling}

Multiflash software/Advanced Redlich-Kwong-Soave (RKSA) Equation Of State (EOS) model were used for 
Table 5. Physical properties of $\mathrm{CaO}$ and $\mathrm{SiO}_{2}$ nanoparticles based on the software's information bank.

\begin{tabular}{cccccc}
\hline Nanoparticle & \multicolumn{5}{c}{ Properties } \\
\cline { 2 - 6 } & $T_{\mathrm{c}}(\mathrm{K})$ & $P_{\mathrm{c}} \times 10^{5}(\mathrm{~Pa})$ & $V_{\mathrm{c}}\left(\mathrm{m}^{3} /\right.$ mole $)$ & Acentric factor & $T_{\mathrm{b}}(\mathrm{K})$ \\
\hline $\mathrm{CaO}$ & 420 & 3.94 & 0.00023 & 0.17 & 280 \\
$\mathrm{SiO}_{2}$ & 440 & 3.76 & 0.00028 & 0.2 & 300 \\
\hline
\end{tabular}

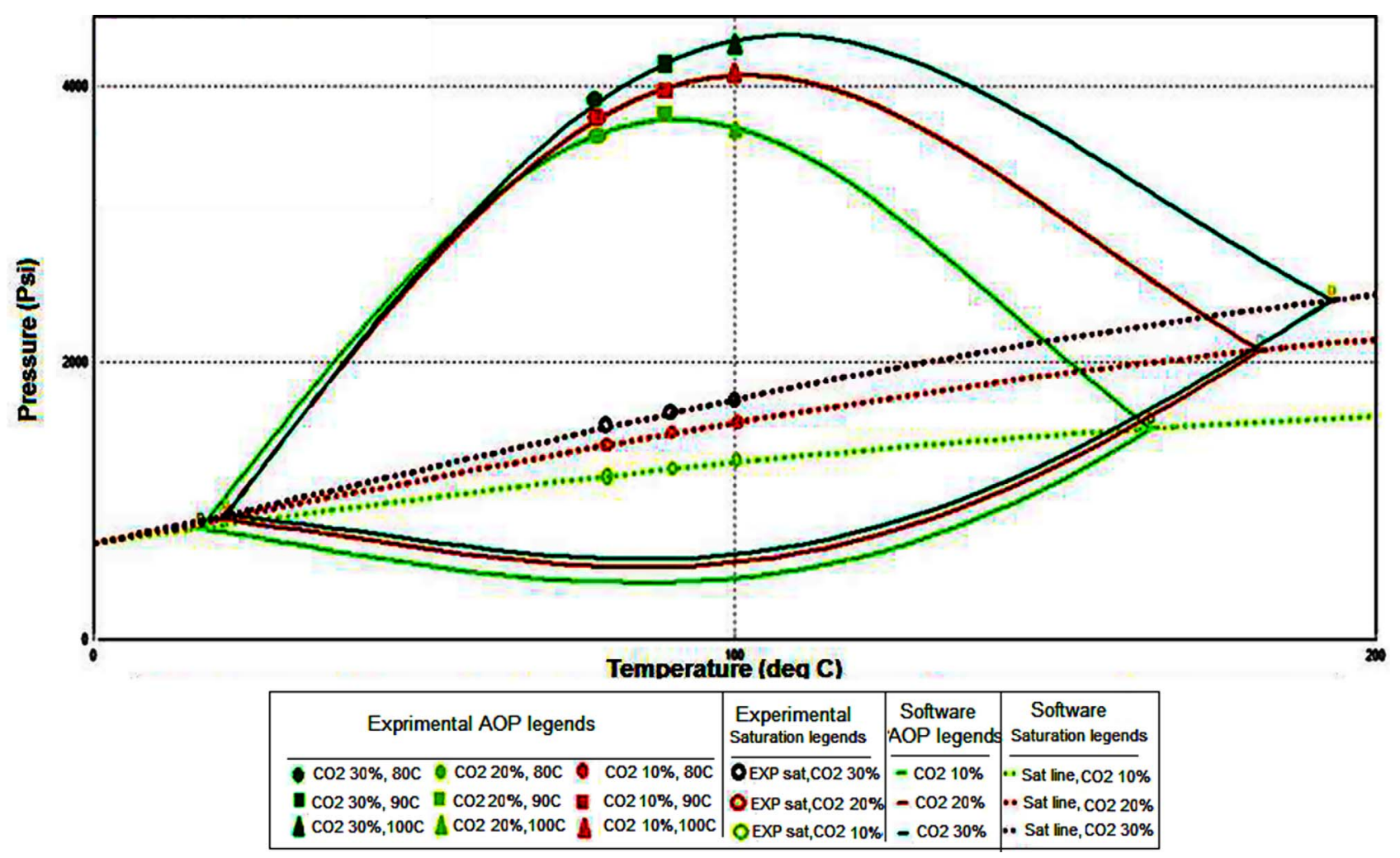

Fig. 7. Effects of $\mathrm{CO}_{2}$ concentrations on APE and saturation pressures.

generating the Asphaltene Precipitation Envelope (APE) in the current study. The RKSA EOS model was stated as Equations (2)-(8), which was proposed by Soave [69].

$$
\begin{gathered}
P=\frac{\mathrm{NRT}}{V-b}+\frac{a}{V(V+b)} \\
a=\sum_{i j} \sqrt{a_{i} a_{j}}\left(1-K_{i j}\right) n_{i} n_{j} \\
b=\sum_{i} b_{i} n_{i} \\
a_{\mathrm{i}}=a_{\mathrm{ci}}\left(1+K_{i}\left(1-\sqrt{ }\left(T / T_{\mathrm{ci}}\right)\right)^{2}\right. \\
K_{i}=C_{\mathrm{o}}+C_{1} W_{i}-C_{2} W_{i}^{2} \\
b_{i}=0.08664 \frac{R T_{\mathrm{ci}}}{P_{\mathrm{ci}}} \\
a_{\mathrm{ci}}=0.42748 \frac{R^{2} T_{\mathrm{ci}}^{2}}{P_{\mathrm{ci}}}
\end{gathered}
$$

where, $P_{\text {ci }}, T_{\text {ci }}, n_{i, j}, W, R$ and $K_{i j}$ are critical pressure, temperature, molar fractions of components, acentric factor, gas constant and binary interaction between components $i$ and $j$.

The ideal inputs for software are: 1) compositional data of crude oil, 2) SARA test result, 3) experimental data for asphaltene flocculation and 4) saturation pressure for tuning petroleum fractions [70]. The main steps of the software include: A) entering inputs, composition, performing split on composition, SARA analysis, and recombination data, B) selecting models, C) entering experimental data and D) plot phase envelope.

\subsubsection{Physical properties of nanoparticles ( $\mathrm{CaO}$ and $\mathrm{SiO}_{2}$ ) based on the software's information bank}

Multiphase flash software does not have the physical properties of nanoparticles, but there is one option that allows introducing any new materials as pseudo components. As the molecular weights of nanoparticles are known, $P_{\mathrm{c}}$, $T_{\mathrm{c}}, V_{\mathrm{c}}$, acentric factor, $T_{\mathrm{b}}$ and other properties are found 


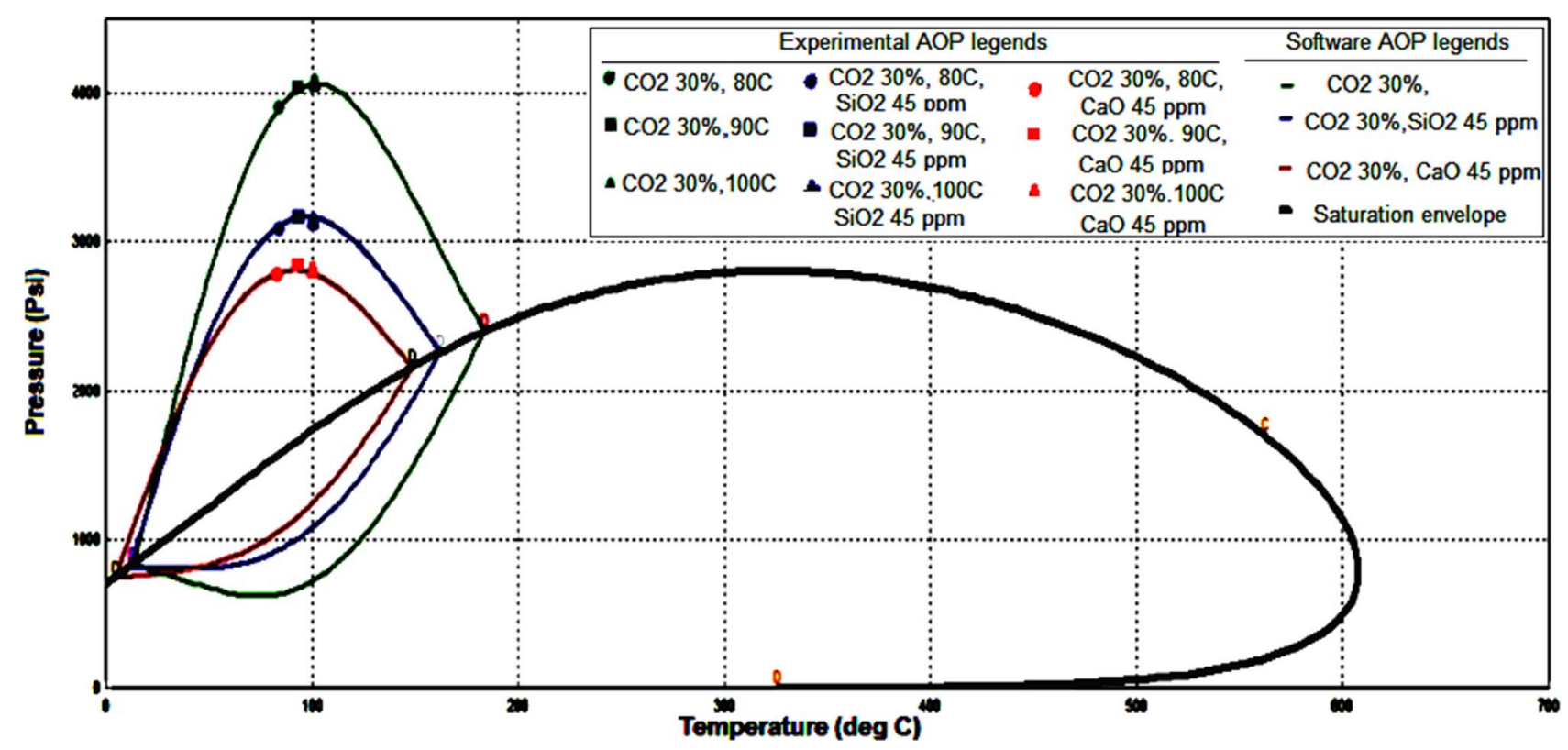

Fig. 8. Effects of nanoparticles $\left(\mathrm{CaO}\right.$ and $\left.\mathrm{SiO}_{2}\right)$ on $\mathrm{APE}$ in the presence of $\mathrm{CO}_{2} 30$ mole $\%$.

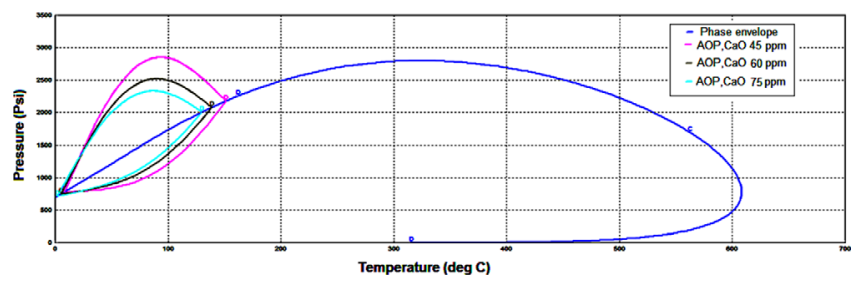

Fig. 9. Prediction effects of increasing $\mathrm{CaO}$ nanoparticle on $\mathrm{APE}$ in the presence of $\mathrm{CO}_{2}$.

based on the software's information bank. Figure 6 shows physical properties of $\mathrm{CaO}$ and $\mathrm{SiO}_{2}$ nanoparticles. Further information is given in Table 5 .

\subsubsection{Effects of $\mathrm{CO}_{2}$ and $\mathrm{CaO}, \mathrm{SiO}_{2}$ nanoparticle concentrations on $A P E$ and saturation pressures based on software}

Figure 7 shows the effects of $\mathrm{CO}_{2}$ concentrations on the APE with software. Based on the software results, as $\mathrm{CO}_{2}$ concentration increased, APE increased, which is in good agreement with the experimental data. Moreover, calculated saturations matched well with the experimental data. As $\mathrm{CO}_{2}$ concentration increased from 10 mole $\%$ to 30 mole $\%$, saturation pressure increased. As it was mentioned before, two different trends were observed in the presence of $\mathrm{CO}_{2} 10$ mole \% for upper onset pressures including 80-90 ${ }^{\circ} \mathrm{C}$ and $90-100{ }^{\circ} \mathrm{C}$. Interestingly, software and experimental data were in good agreement in this case. Figure 8 shows the effects of nanoparticles $\left(\mathrm{CaO}\right.$ and $\left.\mathrm{SiO}_{2}\right)$ on $\mathrm{APE}$ at $\mathrm{CO}_{2} 30$ mole \%. CaO nanoparticles decreased APE

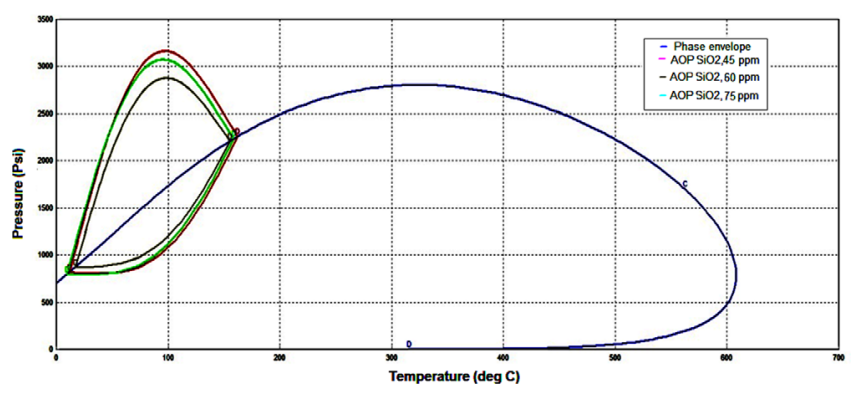

Fig. 10. Prediction effects of increasing $\mathrm{SiO}_{2}$ nanoparticle on $\mathrm{APE}$ in the presence of $\mathrm{CO}_{2}$.

better than $\mathrm{SiO}_{2}$ in the presence of $\mathrm{CO}_{2} 30$ mole \% concentration.

\subsubsection{Prediction effects of $\mathrm{CO}_{2}, \mathrm{CaO}$ and $\mathrm{SiO}_{2}$ nanoparticle concentrations on APE and saturation pressures}

The previous section shows that the software and experimental data were in good agreement with each other. So in the next step, three different tests were designed for predicting the effects of $\mathrm{CaO}$ and $\mathrm{SiO}_{2}$ nanoparticles and $\mathrm{CO}_{2}$ concentrations on APE. The results of these tests were shown in Figure 9, Figure 10 and Figure 11, respectively. As it was observed from the results, the software successfully predicted the effects of both nanoparticles and $\mathrm{CO}_{2}$ concentrations on the APE, and it was applicable for predicting these effects in the range that experimental data did not exist. 


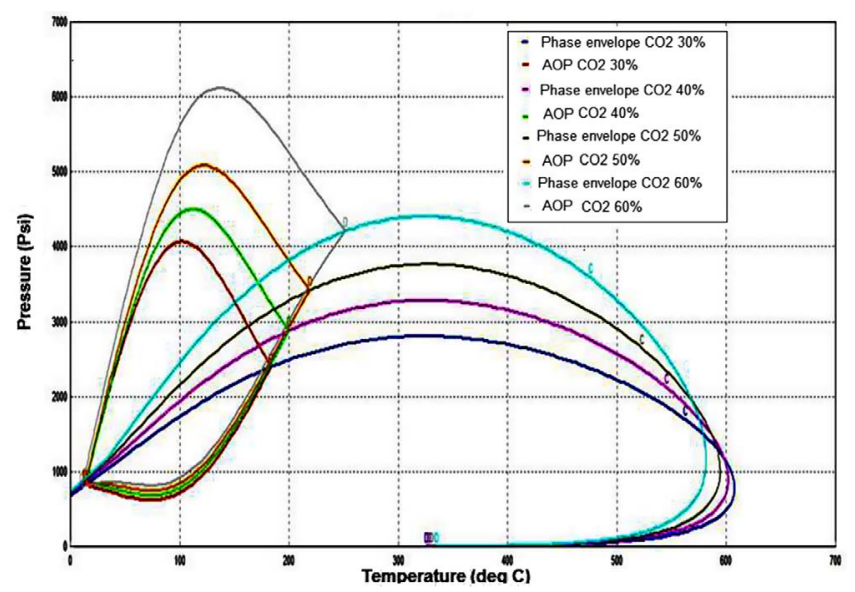

Fig. 11. Prediction effects of increasing $\mathrm{CO}_{2}$ on APE.

\section{Conclusion}

1) At constant $\mathrm{CO}_{2}$ concentration and temperature during natural pressure depletion, the above saturation pressure of asphaltene precipitation increased (density and fluid power decreased), while below saturation pressure asphaltene precipitation decreased (solution gas evolves from crude oil and oil becomes richer).

2) At constant $\mathrm{CO}_{2}$ concentration, as the temperature increased, asphaltene precipitation decreased while it was observed that saturation pressures increased. The reasons were understood from the fact that dilution of oil with light hydrocarbons decreased the amount of resin and asphaltenes flocculated and lost their stability.

3) Based on experimental upper onset and saturation pressures at different temperatures $\left(80{ }^{\circ} \mathrm{C}, 90{ }^{\circ} \mathrm{C}\right.$ and $100{ }^{\circ} \mathrm{C}$ ) and $\mathrm{CO}_{2}$ concentration $(10 \%, 20 \%$ and $30 \%)$ results, there were two different trends including 1) $\mathrm{CO}_{2} 10$ mole $\%$, from $90{ }^{\circ} \mathrm{C}$ to $\left.100{ }^{\circ} \mathrm{C} 2\right) \mathrm{CO}_{2}$ 10 mole $\%$, from $80{ }^{\circ} \mathrm{C}$ to $90{ }^{\circ} \mathrm{C} ; \mathrm{CO}_{2} 20$ mole $\%$, from $80{ }^{\circ} \mathrm{C}$ to $100{ }^{\circ} \mathrm{C}$ and $\mathrm{CO}_{2} 30$ mole $\%$, from $80{ }^{\circ} \mathrm{C}$ to $100{ }^{\circ} \mathrm{C}$. In the first trend, as temperature increased, asphaltene upper onset pressure decreased while in the second trend, asphaltene upper onset pressure increased due to an increase in temperatures. Additionally, it was observed that the second trends were seen in wide ranges of experimental data.

4) According to the precipitation results in the presence of $\mathrm{CaO}$ and $\mathrm{SiO}_{2}$ nanoparticles, as temperature increased from $90{ }^{\circ} \mathrm{C}$ to $100{ }^{\circ} \mathrm{C}$ during pressure reduction from 2500 Psi to 1500 Psi, CaO decreased asphaltene precipitation from (0.32 wt. \%, 0.62 wt. $\%)$ to $(0.096$ wt. $\%, 0.214$ wt. $\%)$ and $\mathrm{SiO}_{2}$ decreased asphaltene precipitation from (0.56 wt. \%, 1.10 wt. $\%)$ to $(0.27$ wt. $\%, 0.52$ wt. \%). Accordingly, hydrophobic $\mathrm{CaO}$ had better applications for reducing asphaltene precipitations compared to the $\mathrm{SiO}_{2}$ nanoparticle.

5) As temperature increased from $80{ }^{\circ} \mathrm{C}$ to $90{ }^{\circ} \mathrm{C}$, AOP increased from 2750 Psi to 2825 Psi and 3100 Psi to 3150 Psi in the presence of $\mathrm{CaO}$ and $\mathrm{SiO}_{2}$, respectively. However, as temperature increased from $90{ }^{\circ} \mathrm{C}$ to $100{ }^{\circ} \mathrm{C}$, AOP decreased from 2825 Psi to 2790 Psi and 3150 Psi to 3130 Psi in the presence of $\mathrm{CaO}$ and $\mathrm{SiO}_{2}$, respectively.

6) Based on the software results, as $\mathrm{CO}_{2}$ concentration increased, APE increased, which is in good agreement with experimental data. Experimental onset and saturation pressures matched well between experimental data and the proposed model.

7) The software successfully predicted the effects of both nanoparticles and $\mathrm{CO}_{2}$ concentrations on $\mathrm{APE}$, and it was applicable for predicting these effects in the range that experimental data did not exist.

Acknowledgments. The author would like to thank Amirkabir laboratory research center for preparing apparatuses for performing the tests.

\section{References}

1 Rogel E., Ovalles C., Moir M. (2010) Asphaltene Stability in Crude Oils and Petroleum Materials by Solubility Profile Analysis, Energy Fuels. 24, 8, 4369-4374.

2 Zekri A.Y., Shedid A.S., Alkashef H. (2001) A novel technique for treating asphaltene deposition using laser technology, in: SPE Permian Basin Oil and Gas Recovery Conference, Midland, Texas, May 15-17, Paper SPE 70050MS.

3 Buriro M., Talib S.M. (2012) Asphaltene precipitation and prevention: A strategy to control asphaltene precipitation, in: SPE/PAPG Annual Technical Conference, Islamabad, Pakistan, December 3-5, Paper SPE 163129.

4 Andeson S.I., Stendy E.H. (1996) Thermodynamics of asphaltene precipitation and dissolution investigation of temperature and solvent effects, Fuel Science Technology Int. J. 14, 1 and 2, 231-287.

5 Gawrys K.L., Spiecker P.M., Kilpatrick P.K. (2003) The Role of Asphaltene Solubility and Chemical Composition on Asphaltene Aggregation, Pet. Sci. Technol. 21, 3 and 4, 461-489.

6 Hammami A., Ferworn K.A., Nighswander J.A., Sverre Over S., Stange E. (1998) Asphaltinic crude oil characterization: an experimental investigation of the effect of resins on stability of asphaltene, Pet. Sci. Technol. 16, 3 and 4, $227-249$

7 Hirschberg A., deJong L.N.J., Schipper B.A., Meijer J.G. (1984) Influence of temperature and pressure on asphaltene flocculation, SPEJ 24, 3, 283-293.

8 Kralova I., Sjöblom J., Øye G., Simon S., Grimes B.A., Paso K. (2011) Heavy crude oils/particle stabilized emulsions, Adv. Colloid Interface Sci. 169, 2, 106-127.

9 Yarranton H.W., Alboudwarej H., Jakher R. (2000) Investigation of asphaltene association with vapor pressure osmometry and interfacial tension measurements, Ind. Eng. Chem. Res. 39, 8, 2916-2924.

10 Hemmati-Sarapardeh A., Alipour-Yeganeh-Marand R., Naseri A., Safiabadi A., Gharagheizi F., Ilani- Kashkouli P., Mohammadi A.H. (2013) Asphaltene precipitation due to natural depletion of reservoir: Determination using a SARA fraction based intelligent model, Fluid Phase Equilib. 354, $177-184$. 
11 Rudyk S., Spirov P. (2014) Upgrading and extraction of bitumen from Nigerian tar sand by supercritical carbon dioxide, Appl. Energy 113, 1397-1404.

12 Östlund J.A., Wattana P., Nydén M., Fogler H.S. (2004) Characterization of fractionated asphaltenes by UV-vis and NMR self-diffusion spectroscopy, J. Colloid Interface Sci. 2712, 372-380.

13 Thawer R., Nicoll D.C.A., Dick G. (1990) Asphaltene deposition in production facility, SPE Prod. Eng. 5, 475-480.

14 Valter Antonio M.B., Mansoori G.A., De Almeida Xavier L.C., Park S.J., Manafi H. (2001) Asphaltene flocculation and collapse from petroleum fluids, J. Pet. Sci. Eng. 32, 217-230.

15 Pedersen K.S., Christensen P.L. (2007) Phase behavior of petroleum reservoir fluids, 1st edn., Taylor and Francis Group, Boca Raton, Florida.

16 Rogel E., Ovalles C., Moir M. (2012) Asphaltene chemical characterization as a function of solubility: effects on stability and aggregation, Energy Fuels 26, 5, 2655-2662.

17 Bouts M.N., Wiersma R.J., Muljs H.M. (1995) An evaluation of new asphaltene inhibitors: laboratory study and field-testing, in: Presented at international symposium on oilfield chemistry in San Antonio, TX February 14-17, SPE 28991.

18 Yen A., Yin Y.R., Asomaning S. (2001) Evaluating asphaltene inhibitors: laboratory tests and field studies, in: $S P E$ International Symposium on Oilfield Chemistry, Houston, TX, February 13-16, SPE paper 65376-MS.

19 Misra S., Baruah S., Singh K. (1995) Paraffin problems in crude oil production and transportation: A review, SPE Prod. ES Fac. 10, 1, 50-54, Paper SPE-28181-PA.

20 Misra S., Abdulla D., Bazuhair M.K., Aboukhsem A.A., Stenger B.A., Al-Katheeri A.B. (2011) Management of asphaltenes deposition in a giant carbonate onshore oil, field, Abu Dhabbi, UAE, SPE Middle East Oil and Gas Show and Conference, Manama, Bahrain, September 25-28, SPE Paper 140278-MS.

21 Alapati R.R., Joshi N. (2013) New test method for field evaluation of asphaltene deposition, in: Offshore Technology Conference, Houston, TX, USA, May 06-09, Paper OTC24168-MS.

22 Akbarzadeh K., Eskin D., Ratulowski J., Taylor S.D. (2011) Asphaltene deposition measurement and modelling for flow assurance of subsea tubings and pipelines, Offshore Technology Conference, Rio de Janeiro, Brazil, October 04-06, Paper OTC-22316-MS.

23 Newberry M.E., Barker K.M. (1985) Formation damage prevention through the control of paraffin and asphaltene deposition, SPE Production Operations Symposium, Oklahoma City, Oklahoma, March 10-12, Paper SPE 13796.

24 Nassar N.N. (2010) Asphaltene adsorption onto alumina nanoparticles: kinetics and thermodynamic studies, Energy Fuels. 24, 8, 4116-4122.

25 Nassar N.N., Hassan A., Carbognani L., Lopez-Linares F., Pereira-Almao P. (2012) Iron oxide nanoparticles for rapid adsorption and enhanced catalytic oxidation of thermally cracked asphaltenes, Fuel 95, 257-262.

26 Nassar N.N., Hassan A., Luna G., Pereira-Almao P. (2013) Kinetics of the catalytic thermooxidation of asphaltenes at isothermal conditions on different metal oxide nanoparticle surfaces, Catal. Today 207, 127-132.

27 Nassar N.N., Hassan A., Pereira-Almao P. (2011) Application of nanotechnology for heavy oil upgrading: catalytic steam gasification/cracking of asphaltenes, Energy Fuels 254, $1566-1570$
28 Nassar N.N., Hassan A., Pereira-Almao P. (2011) Metal oxide nanoparticles for asphaltene adsorption and oxidation, Energy Fuels 25, 3, 1017-1023.

29 Nassar N.N., Hassan A., Pereira-Almao P. (2011) Comparative oxidation of adsorbed asphaltenes onto transition metal oxide nanoparticles, Colloids Surf. A. 384, 1-3, $145-149$.

30 Hlady V., Lyklema J., Fleer G.J. (1982) Effect of polydispersity on the adsorption of dextran on silver-iodide, $J$, Colloid Interface Sci. 87, 395-406.

31 McLean J.D., Kilpatrick P.K. (1997) Comparison of precipitation and extrography in the fractionation of crude oil residua, Energy Fuels 11, 570-585.

32 Lian H.J., Lin J.R., Yen T.F. (1994) Peptization studies of asphaltene and solubility parameter spectra, Fuel 73, 423-428.

33 Pernyeszi T., Patzko A., Berkesi O., Dekany I. (1998) Asphaltene adsorption on clays and crude oil reservoir rocks, Colloids Surfaces A - Physicochem. Eng. Aspects. 137, 373-384.

34 Simon S., Jestin J., Palermo T., Barre L. (2009) Relation between solution and interfacial properties of asphaltene aggregates, Energy Fuels 231, 306-313.

35 Clementz D.M. (1976) Interaction of petroleum heavy ends with montmorillonite, Clays Clay Miner. 24, 312-319.

36 Acevedo S., Ranaudo M.A., Garcia C., Castillo J., Fernandez A. (2003) Adsorption of asphaltenes at the toluene-silica interface: a kinetic study, Energy Fuels 17, 257-261.

37 Czarnecka E., Gillott J.E. (1980) Formation and characterization of clay complexes with bitumen from athabasca oil sand, Clays Clay Miner. 28, 197-203.

38 Crocker M.E., Marchin L.M. (1988) Wettability and adsorption characteristics of crude-oil asphaltene and polar fractions, J. Petrol. Technol. 40, 470-474.

39 Madhusudhana N., Yogendra K., Mahadevan K.A. (2012) Comparative study on photocatalytic degradation of Violet GL2B azo dye using $\mathrm{CaO}$ and $\mathrm{TiO}$ nanoparticles, Int $J$ Eng Res Appl. 25, 1300-1307.

40 Roy A., Samiran S., Bhattacharya M., Bhattacharya J. (2013) Antimicrobial Activity of CaO Nanoparticles, $J$. Biomed. Nanotechnol. 9, 9, 1-8.

41 Hai X.B., Xiao Z.S., Xiaoand H.L., Sheng Y.L. (2009) Synthesis of porous $\mathrm{CaO}$ microsphere and its application in catalyzing transesterification reaction for biodiesel, Trans. Nonferrous Met. 19, 3, 674-677.

42 Wang S., Ma M., Chen S. (2016) Application of PC-SAFT equation of state for $\mathrm{CO}_{2}$ minimum miscibility pressure prediction in nanopores, Presented at SPE Improved Oil Recovery Conference, Tulsa, Oklahoma, USA, April 11-13, Paper SPE 179535.

43 Sun J., Zou A., Sotelo E., Schechter D. (2016) Numerical simulation of $\mathrm{CO}_{2}$ huff- $n$-puff in complex fracture networks of unconventional liquid reservoirs, J. Nat. Gas. Sci., Eng. 31, 481-492.

44 Sun J., Zou A., Schechter D. (2016) Experimental and numerical studies of $\mathrm{CO}_{2}$ EOR in unconventional liquid reservoirs with complex fracture networks, Presented at SPE Improved Oil Recovery Conference, Tulsa, Oklahoma, USA, April 11-13, Paper SPE 179634.

45 Azzolina N.A., Nakles D.V., Gorecki C.D., Peck W.D., Ayash S.C., Melzer L.S., Chatterjee S. (2015) $\mathrm{CO}_{2}$ storage associated with $\mathrm{CO}_{2}$ enhanced oil recovery: A statistical analysis of historical operations, Int. J. Greenh. Gas. Con. 37, 384-397. 
46 Li Z., Gu Y. (2014) Optimum timing for miscible $\mathrm{CO}_{2}$-EOR after water flooding in a tight sandstone formation, Energy Fuels 28, 488-499.

47 Mohammadi M., Akbari M., Fakhroueian Z., Bahramian A., Azin R., Arya S. (2011) Inhibition of Asphaltene Precipitation by $\mathrm{TiO}_{2}, \mathrm{SiO}_{2}$ and $\mathrm{ZrO}_{2}$ Nanofluids, Energy Fuels 25, 7, 3150-3156.

48 Dudášová D., Simon S., Hemmingsen P., Sjöblom J. (2008) Study of asphaltenes adsorption onto different minerals and clays. Part 1. Experimental adsorption with UV depletion detection, Colloids Surf A. 317, 1-9.

49 Lu T., Li Z., Fan W., Zhang X., Lv Q. (2016) Nanoparticles for inhibition of asphaltenes deposition during $\mathrm{CO}_{2}$ flooding, Ind. Eng. Chem. Res. 55, 23, 6723-6733.

50 Leontaritis K.J., Mansoori G.A. (1987) Asphaltene flocculation during oil production and processing: a thermodynamic collodial model, SPE International Symposium on Oilfield Chemistry, San Antonio, Texas, February 4-6, Paper SPE 16258-MS.

$51 \mathrm{Wu}$ J., Prausnitz J.M., Firoozabadi A. (2000) Molecular thermodynamics of asphaltene precipitation in reservoir fluids, AIChE Journal. 46, 1, 197-209.

52 Nghiem L.X., Hassam M.S., Nutakki R., George A.E.D. (1993) Efficient Modelling of Asphaltene Precipitation, SPE Annual Technical Conference and Exhibition, Houston, Texas, October 3-6, Paper SPE 26642-MS.

53 Victorov A.I., Firoozabadi A. (1996) Thermodynamic micellizatin model of asphaltene precipitation from petroleum fluids, AIChE J. 42, 6, 1753-1764.

54 Song S. (2008) Managing flow assurance and operation risks in subsea tie-back system, Offshore Technology Conference, Houston, Texas, USA, May 05-08, SPE paper OTC-19139MS.

55 Fazelipour W. (2011) Predicting asphaltene precipitation in oilfields via the technology of compositional reservoir simulation, SPE International Symposium on Oilfield Chemistry, Woodlands, TX, USA, April 11-13, Paper SPE 141148.

56 Pereira V.J., Setaro L.L.O., Costa G.M.N., de Melo S.A.B. (2017) Evaluation and improvement of screening methods applied to asphaltene precipitation, Energy Fuels 31, 4, 3380-3391.

57 Yen A., Yin Y.R., Asomaning S. (2001) Evaluating asphaltene inhibitors: laboratory tests and field studies, $S P E$ International Symposium on Oilfield Chemistry, Houston, Texas, USA, February 13-16, Paper SPE 65376-MS.

58 Singh N.B., Singh N.P. (2007) Formation of CaO from Thermal decomposition of calcium carbonate in the presence of carboxylic acids, J. Therm. Anal. Calorim. 89, 1, 159-162.
59 Mousavi-Dehghani S.A., Vafaie-Sefti M., Mansoori G.A. (2007) Experimental and theoretical investigation of asphaltene deposition in natural gas injection, Pet. Sci. Technol. 25, 1435.

60 Mousavi-Dehghani S.A. (2004) Experimental and theoretical investigation of asphaltene deposition in natural gas injection, PhD Thesis, Tarbiat Modares University, Chemical Engineering Department, Tehran, Iran.

61 Hassanvand M., Shahsavani B., Anooshe A. (2012) Study of temperature effect on asphaltene precipitation by visual and quantitative methods, J. Pet. Technol. Altern. Fuels 3, 2, 8-18.

62 Verdier S., Carrier H., Andersen S.I., Daridon J.L. (2006) Study of pressure and temperature effects on asphaltene stability in presence of $\mathrm{CO}_{2}$, Energy Fuels 20, 4, 1584-1590.

63 Bahrami P., Kharrat R., Mahdavi S., Ahmadi Y., James L. (2015) Asphaltene laboratory assessment of a heavy onshore reservoir during pressure, temperature and composition variations to predict asphaltene onset pressure, Korean $j$. Chem. Eng. 32, 2, 316-322.

64 Negahban S., Joshi N., Jamaluddin A.K.M., Nighswander J. (2003) A systematic approach for experimental study of asphaltene deposition for an $\mathrm{Abu}$ Dhabi reservoir under WAG development plan, International Symposium on Oilfield Chemistry, Houston, Texas, February 5-7, Society of Petroleum Engineers, Paper SPE 80261-MS.

65 Novosad Z., Costain T.G. (1990) Experimental and Modeling Studies of Asphaltene Equilibria for a Reservoir Under CO2 Injection, SPE Annual Technical Conference and Exhibition, New Orleans, Louisiana, September 23-26, Paper SPE 20530-MS.

66 Srivastava R.K., Huang S.S. (1997) Asphaltene deposition during $\mathrm{CO}_{2}$ flooding: a laboratory assessment, SPE Production Operations Symposium, Oklahoma City, Oklahoma, March 9-11, SPE Paper 37468-MS.

67 Takahashi S., Hayashi Y., Takahashi S., Yazawa N. (2003) Characteristics and Impact of Asphaltene Precipitation during CO2 Injection in Sandstone and Carbonate Cores: An Investigative Analysis Through Laboratory Tests and Compositional Simulation, SPE International Improved Oil Recovery Conference in Asia Pacific, Kuala Lumpur, Malaysia, October 20-21, Paper SPE 84895-MS.

68 Vazquez D., Mansoori G.A. (2000) Identification and measurement of Petroleum Precipitates, Petrol. Sci. Eng. 26, 1-4, 49-55.

69 Soave G. (1972) Equilibrium constants from a modified Redlich-Kwong equation of state, Chem. Eng. Sci. 27, 6, 1197-1203.

70 Multiflash User Guide, (2003) Infochem computer services Ltd, version 3.3. 